Article

\title{
The Impact of Brexit on EU Development Policy
}

\author{
Sophia Price \\ Politics and International Relations, Leeds Beckett University, Leeds, LS1 3HE, UK; E-Mail: sophia.price@leedsbeckett.ac.uk
}

Submitted: 3 March 2019 | Accepted: 15 July 2019 | Published: 16 September 2019

\begin{abstract}
Brexit is likely to herald fundamental changes in the operation, scope and practice of EU development policy, due to the UK's key role in leading and defining the geographical and sectoral remit of policy, and through its provision of large-scale funding. Through a focus on the EU's relations with the African, Caribbean and Pacific (ACP) Group of States, this article explores these potential impacts. It highlights the importance of the timing of Brexit in relation to the contemporaneous renegotiation of EU-ACP relations and the EU's Multiannual Financial Framework and argues that the focus on static impacts of Brexit, in terms of removing the UK from the 'EU equation', overlooks the broader dynamics of political economy in which it is situated. Through the analysis of the anticipatory adjustments and discursive dynamics in EU development policy that articulate the pursuit of material interests, the article helps understand both the dynamics of Brexit and the broader transformations in which it is located.
\end{abstract}

\section{Keywords}

African, Caribbean and Pacific group; Brexit; development policy; European Union

\section{Issue}

This article is part of the issue "The Impact of Brexit on EU Policies", edited by Ferdi De Ville (Ghent University, Belgium) and Gabriel Siles-Brügge (University of Warwick, UK).

(C) 2019 by the author; licensee Cogitatio (Lisbon, Portugal). This article is licensed under a Creative Commons Attribution 4.0 International License (CC BY).

\section{Introduction}

This article draws on the central themes of this Special Issue to explore the impact of Brexit on EU Development Policy, with a specific focus on EU-Africa, Caribbean and Pacific (ACP) relations. Drawing on a materialist political economy approach, the core argument highlights the need to understand EU development relations within their broader context, both in terms of colonial and post-colonial structures and the expansion of the world market. It follows Rosamond's (2016, p. 869) entreaty to study the EU within, rather than isolation from, the broader dynamics of political economy in which it is situated.

Development policy provides a fruitful field in which to explore the impact of Brexit. It necessarily entails the analysis of both the internal and external dimensions of European integration/disintegration. EU development policy is an example of an area of mixed competences between the EU institutions and member states, which has experienced increasing Europeanisation whilst also being greatly influenced by the UK, in terms of funding, policy leadership, expertise and geographical orientation. A specific focus on the EU-ACP relationship provides evidence of these themes, and particularly the legacies of colonialism and pressures of ongoing neoliberal restructuring. In particular the current renegotiation of the EU-ACP Cotonou Partnership Agreement (CPA) provides a useful early test of such impacts on EU development policy, as it has coincided both with preparations for Brexit and internal EU budgetary negotiations for the next Multiannual Financial Framework (MFF). As such it reveals the anticipatory adjustments made by key actors in preparation for the departure of the UK, most notably EU Member states, EU and ACP institutional actors, and associated political and societal interests.

Existing literature on the impact of Brexit on EU development policy has tended to focus on static impacts, particularly in relation to the funding and policy leadership gaps left by the UK's exit. In these terms static impacts refer to the assumed effects on development policy and policy making of simply removing the UK from the 'EU 
equation' (De Ville \& Siles-Brügge, 2019; Jensen \& Snaith, 2018). This article explores this by demonstrating how the Commission and certain member states are utilising the confluence of the renegotiation of the EU-ACP relationship, the MFF and the removal of the UK from this area of policy making, to enhance the Commission's role in the management of development policy. As the UK has historically opposed this integrative pressure, Brexit has provided opportunity to reignite this agenda.

Whilst recognising the importance of the institutional challenges and changes provoked by Brexit, this article however argues for a broader analysis which highlights the more fundamental shifts that are reflective and constitutive of disintegration. It points to the anticipatory adjustments already underway in EU development policy that indicate its dynamic effects, for example the changing preferences and strategies in relation to the geographical and sectoral focus of development policy. Further evidence of such dynamism is the promotion of interests clearly aligned to EU self-interest, defined both as the promotion of EU core policy concerns linked to development, particularly around security and control of migration, and in the material interests in promoting business expansion and the development of markets associated and linked to European capital. The article argues this is represented by the discursive dynamics that explicitly justify the use of development cooperation in self-interested terms. In doing so it reveals the discursive and material struggles emerging as the EU seeks to reframe and promote its own interests alongside UK attempts to reconfigure itself as Global Britain, and throws light on the impact of disintegration on the global role of the EU and its future relations with the UK. Importantly it asserts that that the pursuit of key material and ideational interests in the external relations of the EU and its member states is not new, but is reliant on and reproduces inequitable historic and social conditions that structure contemporary North-South relations.

This argument acknowledges the intertwined relationship between ideas, discourse and their material underpinnings. There is a substantial focus on discourse in materialist approaches. For example, in Gramscian terms, ideas combined with institutional forms and material capabilities, are central to hegemony and dominant social formations. Marx and Engels highlighted how class rule shapes the ruling ideas of each age, and forewarned against their presentation as being in the universal interest (Marx \& Engels, 1974). Ideas and discourse are therefore powerful in both reproducing class relations and concealing their contradictions. The policy discourses within development relationships frequently contain, obscure and further particular material interests, which are presented as if they are of wider benefit. In contemporary development policy, discourse serves to obscure long-running inequalities associated with the continuing legacies of colonialism as well as more immediate aspects of the desires of different blocs (including national blocs) of capital for particular forms of investment and trade flows. This has implications for intra-capitalist competition, for the unequal relationship between capital and labour and a host of other unequal resource and power relations on the basis of gender, nationality and race. Policy discourse and its critical deconstruction then, is of central importance for materialist scholars who seek to answer the crucial question of 'who benefits?'.

In order to explore these debates the article first situates EU development policy within a political economy framework, in order to properly locate the analysis of Brexit within the context of crisis and associated pressures of the expansion of global markets. It then explores the relevance of the EU-ACP relationship to the study of both EU development policy and more broadly the processes of EU integration, by highlighting reform of the relationship from a neo-colonial to neo-liberal framework and the agency of the UK within that. In doing so it draws attention to the scalar significance of the relationship, which links 107 states and over 1.5 billion people across the world through its trade and aid provisions. It also highlights the importance of this particular conjuncture in which the renegotiation of the relationship has coincided with both the EU's internal processes of reordering its future financial mechanisms and the disintegrative forces of Brexit. By understanding the particular contemporary context in which the EU-ACP relationship is located, we are better able to assess the likely impacts of the collision of these forces. In doing so the article explores current debates about the impact of Brexit on development policy in terms of their preoccupation with static impacts. This section focuses on both the internal funding and policy leadership gaps created through Brexit and opportunistic attempts to increase the role and power of the EU institutions in response. In contrast, Section 5 develops the analysis of the dynamic impacts of Brexit through a focus on the anticipatory adjustments evident in the current renegotiation of the EU-ACP relationship and the changing geographical and sectoral focus of EU development policy. By exploring the framing of a post-Brexit EU development policy as the securing of EU self-interest in the context of Brexit, the article argues that the disintegrative moment of the UK's decision to leave the EU has provided an opportunity for the EU to readjust its external focus and influence to the exigencies of a changing and increasingly competitive global economy.

\section{The Political Economy of EU Development Policy}

Colonialism is deep in the DNA of EU development policy. As Nicolaïdis (2015, pp. 285-296) argues, European amnesia allows this colonial legacy to be overlooked in the framings of current forms of development cooperation relations, permitting the EU to distance itself from its past whilst also seeking to secure continuity and collective management of a colonial world slipping out of the grasp of its individual member states. Development policy has been a key mechanism by which the EU 
has maintained existing patterns of production and exchange, albeit within a broader commitment to multiscalar neo-liberalisation. As such policy commitments to global frameworks of sustainability and poverty reduction, as embodied in the Sustainable Development Goals and the post- 2015 consensus, are combined with mechanisms that seek to manage processes of world market expansion and generalised competitiveness within statesociety complexes throughout the Global South, and simultaneously within the EU itself (Price \& Nunn, 2016, p. 454). This is pursued internally through the broadening and deepening of its internal market, and externally through trade liberalisation and development cooperation relations, exposing labour and capital both within the EU and in its partners to increased competition (Price \& Nunn, 2016, p. 462). That this produces polarising and uneven effects is recognised by the EU and so it provides specific development policy mechanisms, such as Aid for Trade (AfT), to offset the damaging effects of neo-liberalisation.

A measure of the importance of this policy domain to the EU's attempts to position itself within a changing global economy has been the ongoing attempts to increase supranational competence within the design and management of EU development policy. Since the turn of the new millennium there has been a range of initiatives to embed a European development policy both centrally and within the member states' own policy frameworks. The EU believes that the collectivisation of development policy strengthens its global actorness and provides "added value, in terms of political and financial leverage, that is larger than the sum of individual Member State actions" (European Commission \& High Representative of the Union for Foreign Affairs and Security Policy [EC \& HRUFASP], 2016a, p. 2). While Orbie and Carbone (2016) point to the limited provision by way of a formal acquis communautaire that bind member states in this area, the 2005 European Consensus on Development and 2011 Agenda for Change stand out in setting common principles and practices, accompanied by specific institutions and budgetary instruments through which European development policy is managed. Delputte, Lannoo, Orbie and Verschaeve (2019) state that while the EU has had an 'outspoken commitment' to both influencing its member states' policies and fostering an enhanced European development policy, pressures for increased Europeanisation have been countered by the endurance of differing member state preferences and national priorities, the relatively weak institutional mechanisms that underpin the EU approach to development and sub-groupings of states that share differing ideas and priorities. However, rather than viewing these as competing binary distinctions between the national and supranational characteristics, authors such as Smith (2016, p. 141) argue that the processes of (re)nationalisations, Europeanisation and globalisation occur in complex co-existence, with the interplay of structures, norms and practices at a variety of scales underpin- ning the shape and operation of EU development policy. An empirical focus on the EU-ACP relationship provides a lens through which to both understand this complexity and the potential effects Brexit will produce.

\section{The EU-ACP Relationship}

The EU-ACP relationship is rooted in the colonial past of EU member states, and reflects attempts to secure continuity and collective management of colonies and former colonies within the context of both the wideranging transitions to independence across the Global South and the deepening and widening of European integration. Originally signed in 1975, in the wake of UK accession, the EU-ACP partnership built on the 1957 Treaty of Rome and subsequent Yaoundé Conventions (1964-1975) which provided for the association of the colonial and post-colonial relations of the original six European Economic Community (EEC) member states. On the accession of the UK, these agreements were reformulated into the Lomé Conventions to accommodate the UK's external relations, particularly its colonies and former colonies in the Caribbean and Anglophone Africa, with the ACP created as a group of states to 'partner' and negotiate with the EU. The UK was therefore central to the creation of the EU-ACP partnership, and has subsequently been a key actor in the ongoing reform of that relationship.

The first Lomé Convention reflected broader global initiatives to address structural inequalities in the Global Economy, as embodied in the United Nations New International Economic Order (NIEO). This included developmental provisions, in particular non-reciprocal preferential trade agreements and commodity stabilization mechanisms. Development assistance was provided through the bespoke European Development Fund (EDF) and was not linked to the forms of economic and political conditionalities that would later define EU aid provision. The EDF has endured as the key EU-ACP aid funding mechanism, sitting outside the European budget and funded directly by member state contributions.

The scale and scope of this relationship has changed over time, not least with the widening of both groups to now encompass 79 ACP states, 28 EU member states and 1.5 billion people. It has undergone continued pressures to liberalise culminating in the replacement of the Lomé Conventions by the CPA in 2000. This restructuring has locked-in longstanding commitments to neo-liberal reform, based on regionalisation and the restructuring of state-society relationships across the ACP. Non-reciprocal trade preferences were replaced by Free Trade Agreements, known as Economic Partnership Agreements (EPAs), between the EU and ACP regional groupings. Aid provision transformed from 'project' to 'programmed aid' and became increasingly conditional on structural adjustment commitments, good governance, respect for human rights, democracy and transparency. A specific focus was placed on AfT and Private 
Sector Development (PSD), with the EU providing 22.5 billion in AfT between 2005 and 2013 (EC \& HRUFASP, 2016b, p. 61). This emphasis on the provision of funding to support trade reform and economic restructuring evidences the EU's concern to offset the negative impacts of neo-liberalisation.

In spite of a rhetorical commitment to trade liberalisation as a route to poverty reduction and economic development, this has had limited impact on pre-existing colonial patterns of trade. Trade diversification, industrialisation strategies and PSD has been limited (EC \& HRUFASP, 2016b, p. 59). The EU remains a major trading partner for the ACP (accounting for $24 \%$ of their imports and $17 \%$ of their exports), and while the ACP as a block has maintained a trade surplus with the EU this is due to the predominance of African mineral exports (EC \& HRUFASP, 2016b, p. 58). ACP agricultural trade remains dependent on primary commodities with little increase in processed, value added products, while the ACP trade surplus fell from $€ 5$ billion to $€ 3$ Billion between 2004 and 2014 (EC \& HRUFASP, 2016b, p. 59). With the current CPA due to conclude in 2020, the EU undertook an extensive evaluation exercise which revealed the limited impact that the CPA has had on poverty reduction, inequality and growth distribution (EC \& HRUFASP, 2016b, p. 93). There has been limited success in the promotion of inclusive growth, in increasing the level of economic participation of the poor and in tackling the root causes of conflict (EC \& HRUFASP, 2016b, p. 120). Moreover, civil society actors, NGOs and domestic ACP businesses have coalesced in anti-EPA movements, recognising the threat posed to their economies from the unrestrained access of large-scale EU enterprises to their markets. While domestic resistance has limited progress on the EPA agenda, the EU has continued to press for the liberalisation of ACP economies.

The contestations arising from the outcomes and effects of EU development policy have not dampened the commitment of either the EU or the ACP to negotiate a successor to the CPA after its expiry in 2020. From an institutional perspective, the EU regards the CPA as providing particular value as a single, predictable, longterm, legally-binding framework with underlying values and principles and a wide-range of instruments, which is ratified by all ACP countries and allows critical mass in financial resources (EC \& HRUFASP, 2016b, p. 132). This has driven the EU's ongoing commitment to the agreement and its replacement. The post-Cotonou negotiations were begun in 2018, but it could not have been foreseen when the original agreement was signed in 2000 , that these would be conducted in the context of the UK's decision to leave the EU and in conditions of such uncertainty.

\section{Exploring the Static Impacts of Brexit}

Existing literature on the impact of Brexit on EU Development Policy has tended to focus on static effects by scenario planning the effect of removing the UK from the "EU equation" (Jensen \& Snaith, 2018). Such analyses rely on understandings of EU's policy-making machinery based on its past behaviour (De Ville \& Siles-Brügge, 2019) and reflects the tendency of neo-functionalism and (liberal) intergovernmentalism to imagine the EU as "institutionally resilient", and of institutionalist approaches to emphasise the "'stickiness' of institutional equilibria" (Rosamond, 2016, p. 866). In this vein, Henökl (2018, p. 64) builds a new institutionalist analysis which highlights the challenges Brexit poses for EU development policy, including existing legal obligations, budget shortfalls, securing business continuity, policy realignment, and representation and membership of international fora. Drawing on an analysis of differentiated integration and regional disintegration, possible scenarios are outlined for post-Brexit EU-UK cooperation which could structure the future of EU development policy. These scenarios are either total rupture and disintegration; selective involvement in some agreements; or strong UK engagement through participation in existing relations (Henökl, 2018, p. 65). The sequenced nature of the Brexit negotiations which requires the approval of the Withdrawal Agreement before the future shape of the UK-EU relationship is agreed, means that at the time of writing this remains undefined. As such, this process of disintegration has an unknown destination and a variety of different policy outcomes (De Ville \& SilesBrügge, 2019)

This indeterminacy provokes scenario planning based on the UK's central role in development policy and funding, and the manner in which UK's colonial legacy, particularly its relations with the Commonwealth, have historically shaped this area of EU policy and condition future interests of both the EU and UK. Brexit therefore raises questions about the EU's capacity to maintain coherence after losing the UK as a coordinator and policy innovator, and the future financing and shape of development cooperation. As such, it brings a threat of instability in EU external relations and possibly an overall reduction in the EU's significance as a global actor. However, opportunities have also been created for member states, institutional and societal actors and third countries to adapt their preferences and behaviour to the absence of the UK. An exploration of the specifities of the EU-ACP relationship in relation to gaps left by the removal of the UK throws some light on the analysis of the static, and more dynamic, impacts of Brexit.

\subsection{The Funding Gap}

In material terms, the loss of UK contributions to EU development funding will pose a particular challenge for the remaining 27 Member States. The EDF has historically been reliant on UK funding, with it contributing $€ 4.5$ billion to the current 11th EDF. This constitutes approximately $15 \%$ of the total EDF, making the UK the third largest contributor (after Germany's $€ 6.28$ billion, 
and France's $€ 5.43$ billion) (DFID, 2013; EU Commission, 2013). Due to the funding cycle, member states contributions to the 11th EDF were due in 2018, giving particular importance to the negotiation of the Withdrawal Agreement and the associated financial 'divorce' settlement, although there was little public discussion of ongoing aid commitments within this. The lack of provisions for a contributor to leave the EDF brought uncertainty, however in 2017 it was confirmed the UK would remain party to the Fund and maintain its existing modalities of payments until it left the EU, with the 2018 Withdrawal Agreement (Articles 129 and 152) making explicit this commitment to Cotonou's institutional structure and funding obligations (EU Commission, 2017; UK Government, 2018). This pragmatic solution represents path dependency and institutional binding resultant from the joint institutions and international legal basis of the CPA.

In the context of Brexit and Cotonou's legal agreement ending in 2020, the impact of the loss of UK funding is less certain, particularly given the declining aid commitments of the remaining $27 \mathrm{EU}$ member states. Between 2010 and 2015 Belgium, Czech Republic, Denmark, Finland, France, Greece, Ireland, Luxembourg, the Netherlands, Portugal and Spain enacted cuts to their aid provision. While there have been some expectations that the remaining member states would compensate of the loss of UK funding, this is uncertain (Castillejo et al., 2018, p. 13). As the EDF has its own legal and institutional basis, it could operate as a 'pan-European development fund' (Olivie \& Perez, 2017, p. 34) giving the UK opportunity to continue to provide funds as a third party. The UK has signalled it is considering the potential for continued funding of EU development instruments, in return for an appropriate yet unspecified role in decision making (European Scrutiny Committee, 2018). However, this is unlikely to be agreed while the negotiations for Brexit, the MFF and the successor to the CPA are ongoing.

\subsection{The Policy Leadership Gap}

Historically, the UK has shown significant leadership in development policy making, with the Department for International Development (DFID) recognised as a leading development actor. Sherriff, Head of European External Action Programme argued that "the UK has had an influence on the EU's focus and expertise on the $0.7 \%$ target for aid, the SDGs [Sustainable Development Goals], the value for money and results agenda, differentiation in EU aid to focus more on least development countries and fragile states" (Laporte, Sherriff, Hauck, \& Bilal, 2016). The UK led innovations in the CPA, particularly the marriage of social policies with trade liberalisation. UK policy makers considered themselves 'determinant actors' in the allocation of EU aid to Least Developed Countries (LDCs), the introduction of transparency as well as "result-orientation" in aid manage- ment and in raising awareness of gender issues (Olivie \& Perez, 2017, p. 21). Haastrup, Wright and Guerrina (2019) argued that the UK has consistently shown leadership in the integration of gender perspectives in development cooperation, to a greater extent than other EU member states or institutions.

The UK proved adept at leveraging EU development provision to achieve DFID's own objectives and national goals, and through the collectivisation of aid, operationalised its impact more extensively than it could have done through bilateral mechanisms (UK Government, 2013). DFID's Multilateral Review (MAR) ranked the EDF 11 out of 43 multilateral organisations for 'good value for money'. This analysis rested on its close alignment with DFID policy, its critical role in meeting international development objectives, and its capacity to extend the reach of UK aid to areas where the UK had a limited and declining aid presence, or where DFID did not operate (DFID, 2013; Watkins, 2016). Furthermore, the UK played a strong coordinating role in the alignment of national, regional and global policy. The UK was at the forefront of coordinating EU policy with the Millennium Development Goals, the SDGs and the post2015 Agenda, forging partnerships with 'like-minded' states (e.g., Nordic States, Ireland, the Netherlands, Luxembourg) to develop a collective approach that promoted a particular form of development and emphasising the benefits and efficiency of collective action (Watkins, 2016). Through such coalitions it played a leading role in the $2005 \mathrm{EU}$ consensus on Development and built momentum for the legal basis for development policy in the Lisbon Treaty (Castillejo et al., 2018, p. 13), whilst also promoting its own priorities at a global level. This underpins the findings of the Independent Commission on Aid Impact (2015) that DFID has significant influence in the multilateral system.

In the facilitation and coordination of consensus across various groupings, the UK acted as a pivotal outlier. Carbone (2012, p. 5) notes that achieving consensus between members states was difficult due to competing preferences. France and Belgium, for example, prioritised their former colonies while others (e.g., Italy, Greece and Central Europe) focused on their immediate neighbours. While the UK played key roles within and between different EU coalitions, there have been questions about the extent to which it has maintained its centrality. There is evidence that the UK has become more of an 'outlier' across time. Sheriff stated that "EU development policy was in a state of evolution even before Brexit, moving to be more aligned with EU self-interest and the SDGs" (Laporte et al., 2016). While others argue that there is a 'strategic deficit' in political leadership in development policy, they point to new coalitions and interests forming in response to the loss of the UK as a powerful development policy actor (Castillejo et al., 2018 , p. 13). Therefore, rather than static responses to the policy leadership gap, this might be an early indication of more dynamic effects emerging. 


\subsection{EDF Reform and Increased 'Europeanisation'}

Reform of the EDF provides a key test of the static impacts of Brexit. Historically, the UK was opposed to Commission proposals to incorporate the EDF into the EU budget, fearing an increase of the Commission's role and the loss of national control. In contrast the Commission has been keen to establish itself as a 'front runner' in the SDGs and has sought to reposition itself by advocating for strong coordination mechanisms to monitor EU and member states activities and the development of a 'whole of government' approach (European Commission, 2019 , pp. 4, 55). This gives weight to institutionalist accounts of Brexit being a critical juncture that gives rise to radical institutional change.

Commission attempts to augment its role in this moment of flux has been met by a lack of consensus and opposition by some member states (Castillejo et al., 2018, p. 10). While there is support for reforming the status quo, there is division over the shape that change should take (Castillejo et al., 2018, p. 10). As with the UK, France, Poland and Hungary have opposed budgetisation, while Germany, Denmark, the Netherlands, Spain and Finland, have been supportive, regarding this as a move to harmonised and coherent external action (Castillejo et al., 2018, pp. 6-10). A further section of member states, broadly described as 'more Eurosceptic', want an overall reduction of the MFF, a reprioritisation of spending, and a focus on adding value (Castillejo et al., 2018, p. 6).

In the context of the removal of the UK from the 'EU equation' the Commission has reinvigorated its proposals to budgetise the EDF and radically reform aid mechanisms as part of the 2021-2027 MFF. Alongside bringing the EDF firmly under the control of EU institutions, it has proposed an increase of $30 \%$ in its external action budget to $€ 123$ billion (European Commission, 2018b). The Commission argues that budgetisation will provide protection from the vulnerabilities of member states declining aid commitments and provide more coherence, greater transparency, democratic scrutiny and flexibility (European Commission, 2018b). The new proposals are based on the Neighbourhood, Development and International Cooperation Instrument, merging a number of EU financing mechanisms into a geographic pillar (with a focus on the neighbourhood and SubSaharan Africa), a thematic pillar and a rapid response pillar. In addition the proposals include an Investment Framework for External Action, with an increased 'firepower' of up to $€ 60$ billion to help raise and leverage additional private sector financial resources (European Commission, 2018b).

The Commission's decision to utilise the confluence of Brexit, the renegotiation of the CPA and the MFF to bring forward this reform demonstrates a degree of opportunism. Lightfoot, Mawdsley and Svent-Ivanyi (2017) note that the Commission has long been 'carving itself a role as coordinator of member state activities', and has signalled its intentions to increase its capacity in this field. The opposition of the UK and other EU Member states has been matched by the ACP who are concerned this could herald a diminution of its aid allocation. The ACP negotiating mandate for the post-2020 relationship therefore makes explicit its firm preference for maintaining the EDF outside of the budget coupled with an emphasis on budget support (ACP, 2018, p. 25). While the coalition of opposition led to the failure of the Commission's previous attempts to budgetise the $E D F$, for example in 2003 in advance of the 10th EDF (European Commission, 2003), in the context of Brexit, it has renewed its proposals.

Importantly the integration of the EDF into the budget would make it difficult for the UK to continue to participate in EU external relations. The principle of thirdparty participation in EU development mechanisms is already established through the financial innovations that allow non-member states to channel their Overseas Development Assistance (ODA) via the EU. The option of maintaining UK EDF funding is broadly in line with ACP preferences to open the post-Cotonou relationship to third parties. Indeed, certain members states' opposition to budgetisation reflects their desire to facilitate the continuation of the UK's contribution (Castillejo et al., 2018, p. 10). The possibility of ongoing UK contributions to the EDF would limit the impact of Brexit on this area of development policy. However, this prospect appears unlikely, not least due to the reduced leadership capacity the UK would inevitably have as an 'outside' contributor, notwithstanding its demands to continue to shape policy in return for its participation.

In light of the indeterminacy of the disintegrative processes, there has been a tendency to focus on scenario planning responses to the gaps left by the UK. Institutionalist and liberal intergovernmentalist accounts provide analyses of the extent to which the remaining EU states and institutions 'fill the gap' left by the UK in funding, policy leadership and policy orientation and/or reshape EU development policy. Within this, the analysis of whether Brexit represents the kind of critical juncture that will induce radical change is key. However, it is perhaps more fruitful to understand this disintegration within a broader set of transformations associated with the expansion of the world market and its inherent tendency to crisis. Here the analysis of the anticipatory adjustments and discursive framings evident in the EU-ACP relationship provide an alternate lens through which to assess the dynamic effects of Brexit.

\section{Anticipatory Adjustments and the Discursive Dynamics in the EU-ACP Relationship}

The focus on the anticipatory adjustments in advance of Brexit speaks to Rosamond's $(2016$, p. 868) analysis of disintegration as an indeterminate, messy and drawn out process mediated by the EU's multi-institutional game. This uncertainty points to the way in which the effects of Brexit on EU development policy will depend on the ad- 
justments made by both societal and institutional actors (De Ville \& Siles-Brügge, 2019) In terms of the EU-ACP relationship these anticipatory adjustments are increasingly apparent in the EU's sectoral and geographic orientation and discursive dynamics.

\subsection{Reorientation of Geographical and Sectoral Focus}

Given the manner in which UK colonial relations have shaped EU external relations, Brexit could herald a redirection of the geographical focus of development policy, posing a particular threat for Commonwealth ACP states. Non-LDC states, such as those in the Caribbean, might experience a reduction in aid due to close links to the UK and the EU preference for a differentiated approach. Laporte (Laporte et al., 2016) suggested "it might be difficult for the English-speaking Caribbean to find new allies in Europe that will defend their case in Brussels". Furthermore, the absence of the UK from the MFF negotiations could mean a greater focus by the EU on middle income countries (Castillejo et al., 2018). Olivie and Perez (2017) suggest that these potential impacts would be compounded by a changing sectoral focus away from social development to infrastructural development and trade facilitation.

Early evidence of a changing geographical focus was clear in the EU's proposal to replace the CPA with three distinct, differentiated regional partnerships within a common umbrella agreement. This would maintain the existing acquis without incurring significant financial costs (EC \& HRUFASP, 2016a, p. 3). These strengthened yet flexible regional partnerships (EU-Africa, EU-Caribbean and EU-Pacific) rely on an increased management role for associated regional organisations, and have a specific set of regional themes. For Africa, this includes a focus on migration and 'mobility management', reflecting the EU's growing concerns about immigration, security and the pressures facing the Southern EU member states. For the Caribbean, which was the first region to conclude an EPA through the CARIFORUM-EU partnership, the specific focus is sustainability, climate change and natural disasters. The EU's relations with the Pacific share a similar set of priorities, highlighting the dependence of the region on maritime security and ocean governance. The Pacific Islands Forum has been identified as a key organisation in the future management of EU-Pacific relations, although without the basis of a region-wide EPA which has proved difficult to conclude and currently only includes Papua New Guinea and Fiji.

While the EU's preference for a more regionalised approach is longstanding, as evidenced in the EPA frameworks, this has been greatly strengthened through the post-Cotonou proposals and the pursuit of the Continent to Continent (C2C) agreement to cement EU-African Union relations. The EU's proposals chime with those of the African Union (AU) and its desire to ensure African Unity and augment EU-AU relations (African Union, 2018). This consensus produced the New Africa
Europe Alliance and is reinforced by the EU's support for African Continental Free Trade Area (ACFTA), which includes increases in financial support from $€ 7$ million (2014-2017) to $€ 50$ Million (2018-2020). The longterm aim is to build a continent-to-continent EU-ACFTA Agreement (European Commission, 2018a). The confluence of the preparations for the post-Cotonou negotiations and for Brexit have therefore provided a unique opportunity for the EU to secure and deepen its regionalised approach to development, and particularly its relations with Africa as a bloc. Its ongoing commitment to principles of poverty reduction however is less certain.

Other dynamic effects of Brexit might become evident through strengthened ACP negotiating power. While the collective ACP has remained committed to maintaining the integrity of the Group, Brexit presents an opportunity for individual states, regions and groups to leverage their position in relation to the EU (Langan, 2016). With the UK potentially offering an alternative set of trade relationships, ACP states could exact concessions from both sides in order to secure their interests. As such, Brexit could create dynamism in the behaviour of third countries, as they seize the opportunity to maximise their positions and gain concessions from the EU. This could signal a rebalancing of the historically asymmetrical EU-ACP relations and limit the EU's power to push its own interests, either geographically or sectorally. The disintegrative momentum therefore could provide opportunity for the ACP to bring a more developmental focus to the relationship and offset the socio-economic pressures wrought through rapid trade liberalisation and associated neo-liberal restructuring.

This potential shift towards more equitable relations has however been countered by the Commission's explicit desire to pursue its own preferences and selfinterest within the new relationship. "The general objective is to shape relations with the ACP countries after 2020 as to best achieve the EU's interests" (EC \& HRUFASP, 2016a, p. 2). Furthermore, the EU's regionalised approach could facilitate the expansion of the EU's external relations. The regional pillar approach provides the opportunity to extend the relationship beyond the existing ACP members, for example to include North African states, other non-ACP LDCs and small island developing states (EC \& HRUFASP, 2016a, p. 3). Therefore, the post-CPA presents an opportunity to expand the global reach of the EU through and beyond existing frameworks, and in doing so poses a particular challenge to the global influence of the UK post-Brexit.

In the context of the EU's intentions to deepen and widen its links to Africa, the UK government has also been signalling its desire to secure its position on the continent. North Africa in particular is an emerging arena of competition. In pursuit of its post-Brexit Global Britain agenda, the UK is rapidly expanding its presence throughout the continent. Former French colonies, such as the rapidly growing frontier markets of Ivory Coast and Senegal, have been identified as areas of interest, 
while new UK embassies have been established in Niger and Chad. However, while these competing positions indicate attempts to secure advantage in potentially lucrative emerging markets and zones of influence, both the UK and EU share common commitments to securing processes of world market expansion and embedding neoliberal reform (Price \& Nunn, 2016, p. 454). Moreover, the adoption and promotion of collectivised investment facilities at the heart of both EU and UK development funding provides opportunities for collaboration. The UK stated that cooperation based on the collective management of investments could be possible if the EU matched the UK's agenda (Mordaunt, 2018). The extent to which this would depend on the City of London's expertise, and the willingness of both the UK and EU to fund collective investments could determine the future shape of their cooperation.

Both DFID and the Commission have enthusiastically supported and promoted collaborative financial Innovations such as aid blending, which combine funding from various public and private channels to generate further investment and leverage large-scale finance (EC \& HRUFASP, 2016b, p. 111). EU aid blending mechanisms such as delegated cooperation and trust funds, allow the participation of non-member states, for example Norway and Switzerland, and offer possibilities for future collaboration with a post-Brexit UK. Member states and non-member states currently contribute to facilities either directly or through investment organisations. For example, PIDG, a key EU trust fund investor, is funded by UK aid in combination with the Netherlands, Switzerland, Australia, Sweden, Germany and the International Finance Corporation (PIDG, 2019). While blended aid mechanisms have expanded rapidly over the last decade, there has been a corresponding decline in budgetary support (EC \& HRUFASP, 2016b, pp. 24-29). This shifting emphasis is in spite of the Commission's evaluation which found that budget support had been most effective in reducing extreme poverty (EC \& HRUFASP, 2016b, p. 93).

The current EDF incorporates two types of trust funds: The Emergency and Post Emergency Trust Fund and the Thematic Trust Funds. The Commission reemphasised its support for such mechanisms in the recent New European Consensus of Development. Examples include the EU-Africa Infrastructure Trust fund, The Caribbean Investment Facility, The Investment Facility for the Pacific, the Africa Investment Facility and the European Fund for Sustainable Development which provides investment guarantees from the EU budget to lower the risks of the expansion of investment (EC \& HRUFASP, 2016b, p. 111). These are augmented by policy innovations such as the 2018 Africa-European Alliance for Sustainable Investment and Jobs which aimed to derisk investment and mobilise private sector financing in Africa (European Commission, 2019, p. 49).

Aid blending has become a key mechanism for the EU to deliver its interest driven development policy. While there has been the strong promotion and proliferation of these public/private finance innovations, Castillejo et al. (2018) argue that there has been a lack of associated mechanisms for reporting and scrutiny. Langan (2018, p. 76) has argued that these mechanisms represent the forms of 'revolving credit' highlighted in neo-colonialist critiques, in which aid is channelled into initiatives that offer opportunities for returns on capital for donor states and allied business interests, often producing negative consequences for labour and the environment and little by way of poverty reduction.

\subsection{The Discursive Dynamics of Brexit}

Long-running neo-colonial and dependency critiques have emphasised the material underpinnings of development policy. In its most recent incarnation however the framing of aid as an investment tool marks a novel discursive turn in which the donor self-interest motive is explicitly promoted and justified. This discourse, rooted in deep material interests, is represented in EU and UK development policy, in struggles to establish presence in areas that were commonly shared prior to Brexit, and in the assurances provided to domestic constituencies of the value of development cooperation.

The 'globalist discourse' (Smith, 2019) of a resurgent Global Britain relies on a reformulation of development policy that closely aligns with the interests of the British state and business, as represented in the 'Value for Money' mantra. This draws heavily on a discursive reinvigoration of the Commonwealth that conjures the notions of Empire and colonialism. Importantly this is framed within a 'Myth of Betrayal' (Murray-Evans, 2016) that ignores the relationships the UK maintained with the Commonwealth through EU membership.

The UK's willingness to express its desire to secure material interests through the discourse of Value for Money in development policy has been matched by the EU. Within the context of enduring effects of global financial crisis and the subsequent sovereign debt crisis in Europe, large-scale migratory pressures, challenges of rising populism and pressures on multilateralism, EU development policy has been shaped by the need to assure domestic constituencies that economic stability, migration and security threats are being addressed. The discursive framing of development cooperation emphasises its potential to deliver returns to Europe and secure the interests of its own citizens and businesses, over the normative commitment to poverty reduction or indeed any sense of post-colonial reparative justice. This framing is increasingly necessary in order to garner member state consensus over the future of EU development policy, particularly where domestic constituencies question policy and funding rationales. Castillejo et al. $(2018, p .6)$ state that in spite of elements of discord between member states and EU institutions, there is support for the promotion of EU interests, particularly when tied to the sustainable provision of global 
public goods. Within this, concepts such as 'sustainable development' and 'poverty reduction' act as important legitimating discourses. However while Brexit produces differing geo-economic imaginaries depending on the way in which ideas are articulated, the EU's commitment to ongoing neoliberalisation is likely to be undisturbed by Brexit (Adler-Nissen, Galpin, \& Rosamond, 2017, pp. 585-586), notwithstanding the driving role the UK has played within the policies and narratives that have structured its development policy.

\section{Conclusion}

Brexit has fundamental implications for the EU's development policies. The loss of the UK will create gaps in funding and policy leadership, and could bring changes to the geographic and sectoral focus of existing relations. Anticipatory adjustments by leading member states, EU institutions and partners have demonstrated the extent to which the confluence of Brexit, the Multi-annual Financial Framework and the EU-ACP negotiations have provided opportunities for change. They also point to the challenges the EU faces in addressing its strategic deficit in policy making and in funding future development cooperation.

While existing analyses offer insight into the institutional impacts of Brexit in terms of filling the gaps left by the UK, they tend to overlook the broader and more fundamental shifts which are both reflective and constitutive of disintegration. The relevance of a materialist political economy approach helps locate the impacts of Brexit within the context of crises and the pressures of the expansion of global markets. By pointing to the anticipatory adjustments being made in terms of a changing geographic and sectoral focus and the discursive turn in policy making towards self-interest and securing material interests, we are better able to understand both the impact that Brexit will have on development cooperation and the EU-ACP relationship. Moreover, it throws light on the impact of disintegration on the global role of the EU and its future relations with the UK. While there is a commonality in their commitment to neo-liberalisation and the expansion of global markets and private investment, the extent to which their own interests are articulated as national, regional or global will determine the future of their relationship. Importantly, Nicolaïdis (2015) reminds us that the pursuit of self-interest and key material and ideational interests in the external relations of the EU and its member states is not novel, but relies on a collective amnesia about the historic and social conditions that fashion contemporary North-South relations and the asymmetries that underpin them. The extent to which Brexit will resolve these remains uncertain.

\section{Acknowledgments}

I would thank the anonymous reviewers and the editors of this thematic issue for their helpful comments and feedback. Any errors or omissions are of course my own.

\section{Conflict of Interests}

The author declares no conflict of interests.

\section{References}

Adler-Nissen, R., Galpin, C., \& Rosamond, B. (2017). Performing Brexit: How a post-Brexit world is imagined outside the United Kingdom. The British Journal of Politics and International Relations, 19(3), 573-591.

Africa, Caribbean and Pacific. (2018). ACP negotiating mandate for a post-Cotonou partnership agreement with the European Union. Retrieved from http://www.acp.int/sites/acpsec.waw.be/files/ acpdoc/public-documents/ACP0001118_\%20ACP_ Negotiating_Mandate_EN.pdf

African Union. (2018). The African Union Executive Council adopts the African Common Position for negotiations of a new cooperation agreement with the EU. Retrieved from https://au.int/sites/ default/files/pressreleases/34065-other-cap20eu20 partnership20pr-20dkane.pdf

Carbone, M. (2012). Between EU actorness and aid effectiveness: The logics of EU aid to Sub-Saharan Africa. Paper presented at the Annual Meeting of the Società Italiana di Scienza Politica (SISP), University of Rome III, Italy.

Castillejo, C., Keijzer, N., Chmiel, O., Di Clommo, M., Jokela, J., Lundsgaarde, E., . . . Venturi, B. (2018). Financing EU external action: Understanding member state priorities. Retrieved from https://ettg.eu/wp-content/uploads/2019/01/ Financing-EU-external-action.pdf

De Ville, F., \& Siles-Brügge, G. (2019). The impact of Brexit on EU policies. Politics and Governance, 7(3), 1-6.

Delputte, S., Lannoo, S., Orbie, J., \& Verschaeve, J. (2019). Does the EU matter in development policy? A multilevel regression analysis of the level and evolution of member state's aid allocations. Retrieved from https://www.researchgate.net/ publication/331552974_Does_the_EU_matter_ in_development_policy_A_multilevel_regression_ analysis_of_the_level_and_evolution_of_Member_ States\%27_aid_allocationsMarch2019

Department for International Development. (2013). Explanatory memorandum for the internal agreement between the representative of the governments of the member states of the European Union. Retrieved from https://www.gov.uk/government/uploads/ system/uploads/attachment_data/file/296189/ No._07_Cm_8818_EU_Financing_of_Aid_2014_to_ 2020.pdf

European Commission, \& High Representative of the Union for Foreign Affairs and Security Policy. 
(2016a). Joint staff working document executive summary of the impact assessment (22.11.2016 SWD (2016)381final). Strasbourg: European Commission.

European Commission, \& High Representative of the Union for Foreign Affairs and Security Policy. (2016b). Executive summary: Evaluation of the Cotonou Partnership Agreement (SWD[2016]250). Strasbourg: European Commission.

European Commission. (2003). Towards the full integration of cooperation with ACP countries in the EU budget (Communication from the Commission to the Council and the European Parliament). Retrieved from http://brussels.cta.int/dnload/en/ european_development_fund_en.pdf

European Commission. (2013). Internal agreement 11th EDF. Official Journal of the European Union (L210/16.8.2013). Brussels: European Commission.

European Commission. (2017). .Joint report from the negotiators of the European Union and the United Kingdom government on progress during phase 1 of negotiations under Article 50 TEU on the United Kingdom's orderly withdrawal from the European Union (TF50 (2017) 19-Commission to EU27). Brussels: European Commission.

European Commission. (2018a). Communication on a new Africa-Europe alliance for sustainable investment and jobs: Taking our partnership for investment and jobs to a next level (Communication from the Commission to the European Parliament, The European Council and the Council Brussels) (12.9.2018 COM(2018) 643 final). Brussels: European Commission.

European Commission. (2018b). EU budget: Making the EU fit for its role as a strong global actor. European Commission. Retrieved from http://europa.eu/rapid/ press-release_IP-18-4086_en.htm

European Commission. (2019). 2019 EU report on policy coherence for development. Brussels: European Commission. Retrieved from https:// ec.europa.eu/europeaid/sites/devco/files/swd_ 2019_20_pcdreport.pdf

European Scrutiny Committee. (2018). New EU partnership with Africa, the Caribbean and the Pacific. (393670,15720/17+ADD1,COM(17)763). Retrieved from https://publications.parliament.uk/pa/ cm201719/cmselect/cmeuleg/301-xxvii/30107.htm

Haastrup, T., Wright, K. A. M., \& Guerrina, R. (2019). Equality after Brexit: Revisiting the myth of the EU as a gender equal polity. Politics and Governance, $7(3)$, 62-71.

Henökl, T. (2018). How Brexit affects EU external action: The UK's legacy in European International Cooperation. Futures, 97, 63-72.

Independent Commission on for Aid Impact. (2015). How DFID works with multilateral agencies to achieve impact (No. 44). London: Independent Commission on for Aid Impact. Retrieved from https://icai.independent.gov.uk/wp-content/
uploads/ICAI-Report-How-DFID-works-withmultilateral-agencies-to-achieve-impact.pdf

Jensen, M., \& Snaith, H. (2018). Brexit and the European Union: Hanging in the balance? In P. Diamond, P. Nedergaard, \& B. Rosamond (Eds.), The Routledge handbook of the politics of Brexit (pp. 254-265). Abingdon: Routledge.

Langan, M. (2016). Brexit and trade ties between Europe and the Commonwealth States in Sub-Saharan Africa. The Round Table, 105(5), 477-487.

Langan, M. (2018). Neo-colonialism and the poverty of 'development' in Africa. Basingstoke: Palgrave.

Laporte, G., Sherriff, A., Hauck, V., \& Bilal, L. (2016). Brexit: First post-referendum thoughts. ECDPM. Retrieved from http://ecdpm.org/talking-points/ brexit-first-post-referendum-thoughts/

Lightfoot, S., Mawdsley, E., \& Svent-Ivanyi, B. (2017). Brexit and UK international development policy. The Political Quarterly. https://doi.org/10.1111/1467923X.12369

Marx, K., \& Engels, F. (1974) The German ideology. London: Lawrence and Wishart.

Mordaunt, P. (2018). The future of UK aid post-Brexit (Speech by International Development Secretary, the Rt. Hon. Penny Mordaunt MP). Retrieved from https://www.gov.uk/government/speeches/thefuture-of-uk-aid-post-brexit

Murray-Evans, P. (2016). Myths of Commonwealth betrayal: UK-Africa trade before and after Brexit. The Round Table, 105(5), 489-498.

Nicolaïdis, K. (2015) Southern barbarians? A postcolonial critique of EUniversalism. In K. Nicolaïdis, B. Sébe, \& G. Maas (Eds.), Echoes of empire: Memory, identity and colonial legacies (pp. 283-303). London: I.B. Tauris.

Olivie, I., \& Perez, A. (2017). Possible impacts of Brexit on EU development and humanitarian policies (Study for the European Parliament Committee on Development). Strasbourg: European Parliament. Retrieved from http://www.europarl.europa.eu/RegData/ etudes/STUD/2017/578042/EXPO_STU(2017) 578042_EN.pdf

Orbie, J., \& Carbone, M. (2016). The Europeanisation of development policy. European Politics and Society, 17(1), 1-11.

PIDG. (2019.) Our owners. PIDG. Retrieved from https:// www.pidg.org/about-us/our-owners

Price, S., \& Nunn, A. (2016). Managing neo-liberalisation through the sustainable development agenda: The EU-ACP trade relationship and world market expansion. Third World Thematics, 1(4), 454-469.

Rosamond, B. (2016). Brexit and the problem of European disintegration. Journal of Contemporary European Research, 12(4), 864-871.

Smith, M. (2016). Conclusions: Europeanisation, globalisation of (re)nationalisation? Revisiting development policy in the European Union. European Politics and Society, 17(1), 136-141. 
Smith, M. (2019). Britain, the European Union and the global arena: In search of post-Brexit roles. Politics and Governance, 7(3), 83-92.

UK Government. (2013). Review of the balance of competences between the United Kingdom and the European Union. London: UK Government. Retrieved from https://www.gov.uk/government/uploads/ system/uploads/attachment_data/file/227437/ 2901086_Foreign_Policy.acc.pdf

UK Government. (2018). Withdrawal Agreement and political declaration on the future relationship between the UK and the EU. London: UK Government. Retrieved from https://www.gov.uk/government/ publications/withdrawal-agreement-and-politicaldeclaration

Watkins, K. (2016). What would Brexit mean for EU development assistance? Devex. Retrieved from http://www.devex.com/news/what-would-a-brexitmean-for-eu-development-assistance- 88265

\section{About the Author}

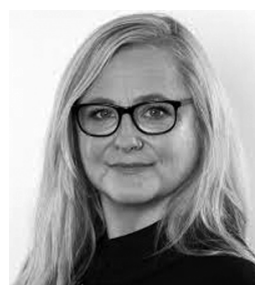

Sophia Price is Head of Politics and International Relations at Leeds Beckett University. Her research covers EU-Africa relations, with a particular focus on West Africa, UK aid policy and feminist political economy. She has recently published work on microfinance and gendered financial inclusion strategies, the impact of Brexit on UK aid policy, and a co-edited book, with Mark Langan, entitled Sustainable Development in Africa-EU Relations. In addition, she co-edits the Lynne Rienner series, Advances in International Political Economy. 